\title{
DISTRIBUTION AND PRESENT NUMBERS OF THE TREE FROG HYLA ARBOREA IN ZEALAND FLANDERS, THE NETHERLANDS (AMPHIBIA, HYLIDAE)
}

\author{
by \\ ANTON H. P. STUMPEL \\ Research Institute for Nature Management (RIN), Department of Zoology, \\ P.O. Box 9201, 6800 HB Arnhem, The Netherlands
}

\begin{abstract}
A distribution survey of Hyla arborea has been carried out in the western part of Zealand Flanders over a period of six years. Additional data on the eastern part and the neighbouring Belgian area have been collected. The relationship between the maximum number of males calling on one evening/night and the estimate of their population size is a suitable basis to predict the total number of males in other pools during a season. Methodological aspects of the fieldwork are discussed. Great fluctuations in presence and activity of the Tree Frog illustrate the need for longterm surveys. Hyla arborea is declining, and nowadays its distribution is restricted to some localities in the western part of the region. These localities are classified according to the number of males and their importance for conservation.
\end{abstract}

\section{RÉSUMÉ}

Des recherches sur la distribution de Hyla arborea ont ète poursuivies pendant six années dans la partie occidentale de la Flandre Zélandaise, des observations supplémentaires ayant été réalisées dans la partie orientale ainsi que dans la zone belge avoisinante. La relation entre nombre maximum de mâles appelant pendant une soirée/nuit et nombre évalué des mâles de la population est une bonne base pour prédire le nombre total des mâles dans d'autres pièces d'eau pendant une saison. On discute les aspects méthodologiques du travail de terrain. Les importantes fluctuations dans la présence et l'activité de la Rainette arboricole montrent que des études de longue haleine sont nécessaires. Hyla arborea est une espèce en déclin et sa distribution dans la région se limite actuellement à certaines localités de sa partie occidentale. Ces localités sont classées suivant le nombre de mâles qu'elles hébergent et leur importance pour la conservation.

\section{INTRODUCTION}

In The Netherlands, the Tree Frog Hyla arborea (Linnaeus, 1758) reaches the northwestern border of its distribution area. Its range is limited to parts in the east and south of the country. During the last few decades, the Tree Frog decreased markedly and became a threatened species (Van de Bund, 1964; Luiken, 1970; Van Roon, 1973; Burny, 1976; Bergmans, 1981; Stumpel, 1981a \& b; Broen \& Vergoossen, 1983; Stumpel \& Hanekamp, 1984; Stortelder \& Reyrink, 1985; Bergmans \& Zuiderwijk, 1986). At present, the Tree Frog can be found in four isolated areas: the region of Achterhoek and Twente (provinces of Gelderland and Overijssel), the central part of the province of Limburg, the central part of the province of North Brabant, and the western part of Zealand Flanders (province of Zealand) (Bergmans \& Zuiderwijk, 1986). The Tree Frog area in Zealand Flanders extends for some kilometres to the west across the Belgian border.

Since 1981 a field study has been carried out in Zealand Flanders, focusing on the distribution, ecology, population dynamics, and habitats of the Tree Frog (Stumpel \& Hanekamp, 1986). The field study is to lead to directives for conservation and management of its habitats. This is the first report, dealing with the results of the distribution survey during the period 1981-1986.

\section{SURVEY AREA}

Zealand Flanders is the southernmost part of the province of Zealand, situated in the southwest of The Netherlands (fig. 1). It covers $880 \mathrm{~km}^{2}$, and is isolated from the rest of The Netherlands by the West Scheldt (a part of the RhineScheldt estuary). In the south it borders on the Belgian 


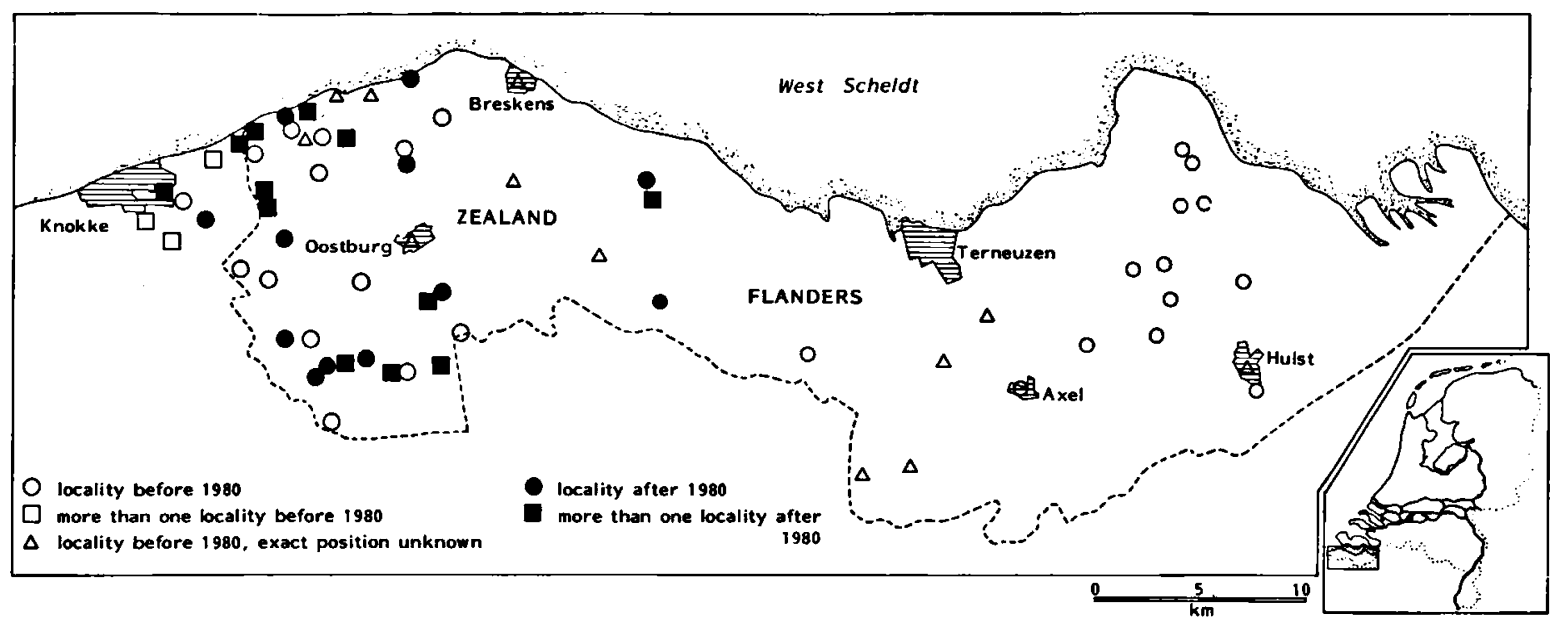

Fig. 1. Present and former distribution records of Hyla arborea in Zealand Flanders. Data from different origins; see text.

provinces of West and East Flanders. The area is rich in salt and brackish waters, particularly land-locked creeks. Fresh water is rather scarce, a reason for man to dig many pools in the past.

Fieldwork has been carried out almost exclusively in a study area (approx. $250 \mathrm{~km}^{2}$ ) west of coordinate $x=30$ of the Amersfoort grid (fig. 2). This report considers the whole area of Zealand Flanders, although no systematical fieldwork has been carried out in the eastern part. Some additional searching has been done in the neighbouring Belgian area, so as to cover the total distribution range in this part of The Netherlands and Belgium.

\section{METHODS}

Before the fieldwork started, the potential spawning sites, such as cattle drinking pools, ponds, shallow parts of canals, and other small waters, were mapped. Not all the pools were reproduced on the topographical maps, particularly small cattle drinking pools were lacking, and moreover, some were well hidden in the landscape. This meant that some pools were only found later during the survey. The direct surroundings of these sites were considered potential land habitats. Salt waters were not taken into account.

During the years 1981-1983 and 1986, the presence of the Tree Frog was recorded systematically. The majority of the potential reproduction sites were visited at least three times yearly during the reproduction period. In the period 1984-1986 only a number of selected localities were studied, but those were more intensively, and particularly so in the village of Retranchement, situated against the Belgian border. Additional data were collected on other waters and land habitats in Zealand Flanders for that period.
The presence of the Tree Frog was recorded by three methods:

- searching for males calling spontaneously or in reaction to tape-recorded mating calls;

- searching in the water for eggs, tadpoles, juveniles and adults;

- searching in the terrestrial vegetation for juveniles and adults.

To be able to make quantitative comparisons, these methods were used as evenly as possible for all the potential reproduction sites. All the waters where one calling male was recorded were considered to be Tree Frog sites, even if eggs, tadpoles or juveniles were never found there.

By catching as many males as possible on evenings with high calling activity and adding up the remaining noncatchable calling males, the minimum numbers of Tree Frogs present on a spawning site were established.

All Tree Frogs caught were marked individually, with the exception of first-calendar-year juveniles. After every capture the animals were released at the very spot where they had been caught.

For additional distribution data on Zealand Flanders for the period before the distribution survey, literature and files were searched and people interviewed.

\section{RESULTS}

\section{Distribution}

Table I gives the position of the sites, and the years in which Tree Frogs were found. All the Tree Frog waters were situated in grassland or arable land that had recently been converted from grassland, except for one site in a marsh, 
one in a dune shrub vegetation, and one in a cellar. The majority of the waters were used as cattle drinking pools. In the western study area 471 potential spawning waters were localized, but in only $52(=11 \%)$ was the presence of Tree Frogs established at least once (Stumpel, in press).

The Tree Frogs were observed in and at the edges of the spawning water, or in the nearby vegetation. As a rule they were found within about $300 \mathrm{~m}$ from a spawning site. In view of this distance a grid with quadrats of $500 \times 500$ $\mathrm{m}$ was chosen to match the distribution pattern (fig. 2). Actual water and land habitats together covered 35 out of the 952 quadrats $(=4 \%$ ). (In four of these quadrats observations were only made in the terrestrial vegetation, but always near spawning sites.) The sites were both inland and close to the coast. Some Tree Frogs were found on the seaward side of the dunes up to 2 $m$ from the beach.

Not all Tree Frog sites were localized during the survey. R. Beijersbergen (pers. comm.) observed five calling males in the Groedse Duintjes area (cf. table I) during the survey period, a site also visited several times within the scope of the survey, but always without success. An unconfirmed record of one calling male came from Oostburg for 1983 and 1984.

A remarkable situation arose in Retranchement where Tree Frogs were found regularly in a cellar hole with some centimetres of water at the bottom. This site was in the pavement in front of a house in a street without any vegetation, with the land habitats at the back of the same house. Up to 17 adults at a time were found there during the reproduction period.

About $5 \mathrm{~km}$ eastward of the study area Beijersbergen discovered Tree Frogs on three sites near Driewegen in 1981 (pers. comm.). Two calling males were heard in a pool that has been infilled meanwhile (Amersfoort coordinates 33.060/374.850); and ten specimens were perceived in a cattle drinking pool (no. 596). In a complex of three pools (nos. 302,303 and 304) inside the hamlet of Driewegen, 15 calling males were found. The presence of Tree Frogs in these four pools could be reconfirmed

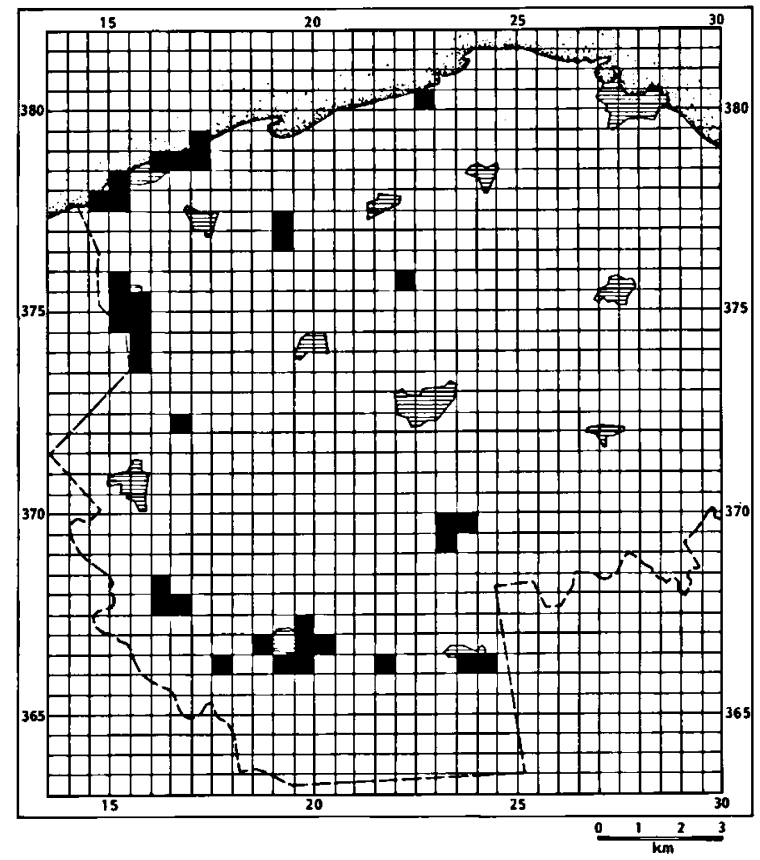

Fig. 2. Distribution of $H$ yla arborea (aquatic and terrestrial habitats, black quadrats) in the study area in western Zealand Flanders for 1981-1986. Coordinates according to the Amersfoort grid (quadrats of $0.25 \mathrm{~km}^{2}$ ). Hatched areas indicate urban environments.

in 1986. One adult was found in 1985 in a garden at Pyramide, $5 \mathrm{~km}$ south of Driewegen (Mrs. L. Butler, pers. comm.).

Some additional searching in eastern Zealand Flanders up to 1986 failed to reveal any Tree Frog (this survey; G. Sponselee, pers. comm.; Lenders, 1986).

Across the Belgian border, between Knokke and Retranchement, Tree Frogs were found in three pools in 1986 (table I).

During the survey period six spawning sites were abandoned as a result of infilling, whereas two others became strongly polluted by dumping dung and rubbish. One overgrown pool was restored for the Tree Frogs.

As to the former distribution of Hyla arborea in western Zealand Flanders, J. M. Burny carried out a survey in the area during the years 19751977. He recorded 26 spawning sites (Burny, 1976); in nine of these, Tree Frogs were never found in the present survey (Burny, cor- 


\section{TABLE I}

List of waters and one isolated land habitat with Tree Frog records during the survey. Number of the waters according to the RIN files, coordinates to the Amersfoort grid (cf. fig. 2)

\begin{tabular}{|c|c|c|c|c|}
\hline Locality & $\begin{array}{l}\text { Water no. } \\
\text { or site }\end{array}$ & Coordinates & Year of record & Remarks \\
\hline \multirow[t]{12}{*}{ Retranchement } & 1 & $15.640 / 375.050$ & $80,81,82,83,84,85,86$ & \\
\hline & 2 & $15.110 / 375.350$ & $81,83,85,86$ & \\
\hline & 3 & $15.150 / 375.275$ & 86 & \\
\hline & 4 & $15.020 / 375.300$ & 85 & \\
\hline & 25 & $15.340 / 375.000$ & 85,86 & \\
\hline & 26 & $15.620 / 374.590$ & $81,83,84,85,86$ & \\
\hline & 27 & $15.560 / 374.550$ & 85 & \\
\hline & 28 & $15.550 / 374.630$ & 85 & $\begin{array}{l}\text { transformed by excavation } \\
\text { in } 85\end{array}$ \\
\hline & 234 & $15.500 / 375.450$ & $82,83,84,85,86$ & \\
\hline & 255 & $15.920 / 375.300$ & 85 & \\
\hline & Veste & $15.575 / 374.540$ & $83,85,86$ & partially transformed in 85 \\
\hline & cellar & $15.530 / 375.030$ & $81,82,83,84,85,86$ & \\
\hline \multirow[t]{2}{*}{ Terhofstede } & 30 & $15.640 / 373.960$ & 83,85 & infilled in 86 \\
\hline & 256 & $15.840 / 374.025$ & 85,86 & \\
\hline \multicolumn{5}{|l|}{ Oudelandse Polder } \\
\hline \multirow[t]{2}{*}{ Northwest } & 9 & $14.810 / 377.720$ & $79,81,82,83,85,86$ & \\
\hline & 10 & $15.050 / 377.820$ & 81 & infilled in 82 \\
\hline \multirow[t]{2}{*}{ Kievittepolder } & 11 & $15.140 / 378.010$ & $81,82,83,85,86$ & \\
\hline & 217 & $15.170 / 378.130$ & 82 & \\
\hline \multirow[t]{2}{*}{ Vlamingpolder } & 13 & $16.630 / 378.710$ & $\begin{array}{l}78,79,80,81,82,83,84 \\
85,86\end{array}$ & \\
\hline & 246 & $17.430 / 378.930$ & $83,84,85,86$ & \\
\hline Cadzand-Bad & 14 & $16.580 / 378.620$ & 82,86 & \\
\hline \multirow[t]{3}{*}{ Knokkert } & 19 & $19.260 / 376.910$ & $80,81,82,83,84,85,86$ & \\
\hline & 20 & $19.210 / 377.125$ & $83,84,85$ & \\
\hline & 218 & $19.350 / 376.910$ & 83,85 & restored in 82 \\
\hline Marolleput & 57 & $22.440 / 375.630$ & 83 & \\
\hline Groedse Duintjes & 221 & $22.600 / 380.300$ & 81 & \\
\hline Kasteelpolder & 32 & $16.590 / 372.360$ & 83 & \\
\hline Kruisdijk & 44 & $16.390 / 367.950$ & $81,82,83,85,86$ & \\
\hline \multirow[t]{13}{*}{ Aardenburg } & 47 & $19.975 / 366.620$ & $81,82,83,86$ & \\
\hline & 174 & $19.550 / 366.280$ & $81,82,83,86$ & \\
\hline & 175 & $19.610 / 366.225$ & $81,82,83,86$ & \\
\hline & 176 & $19.675 / 367.000$ & $81,82,86$ & \\
\hline & 177 & $19.730 / 366.930$ & 81 & infilled in 82 \\
\hline & 179 & $19.860 / 366.820$ & 81,82 & reduced yearly by infilling \\
\hline & 181 & $20.340 / 366.630$ & $81,82,83,86$ & \\
\hline & 182 & $20.180 / 366.960$ & 81,86 & \\
\hline & 202 & $19.440 / 366.420$ & $81,82,86$ & reduced in 83 \\
\hline & 203 & $19.400 / 366.360$ & $81,82,83,86$ & \\
\hline & 211 & $19.220 / 366.360$ & 82,86 & \\
\hline & 299 & $19.890 / 366.290$ & 83,86 & reduced in 83 \\
\hline & ditch & $18.550 / 366.750$ & 86 & \\
\hline Heille & 472 & $17.730 / 366.275$ & 86 & \\
\hline \multirow[t]{5}{*}{ Sint Kruis } & 186 & $21.930 / 366.400$ & 86 & \\
\hline & 195 & $23.900 / 366.410$ & 82 & \\
\hline & 197 & $24.375 / 366.360$ & 81,82 & $\begin{array}{l}\text { transformed by excavation } \\
\text { in } 82\end{array}$ \\
\hline & 198 & $24.430 / 366.280$ & 81 & infilled in 82 \\
\hline & 380 & $21.530 / 366.130$ & 86 & \\
\hline
\end{tabular}




\begin{tabular}{lllll}
\hline Locality & $\begin{array}{l}\text { Water no. } \\
\text { or site }\end{array}$ & Coordinates & Year of record & Remarks \\
\hline Margueritepolder & 109 & $23.980 / 369.590$ & $81,82,83$ \\
Nieuwe Passageule & & & \\
Polder West & 110 & $23.410 / 369.475$ & 83 \\
& 112 & $23.450 / 369.670$ & 83 \\
& 113 & $23.210 / 369.530$ & 83 \\
& 117 & $23.460 / 369.200$ & 83,86 \\
Driewegen & 302 & $34.270 / 374.230$ & 81,86 \\
& 303 & $34.370 / 374.300$ & 81,86 \\
& 304 & $34.220 / 374.280$ & 81,86 \\
Pyramide & 596 & $33.860 / 375.130$ & 81,86 \\
De Vrede (Belgium) & pond & $34.880 / 369.500$ & 85 \\
Het Kalf (Belgium) & pond & $12.950 / 373.880$ & 86 \\
& pond & $10.875 / 374.680$ & 86 \\
\hline
\end{tabular}

respondence; table II). Apart from Burny's data only few concrete old data are available (Schouten, 1899; Van Male, 1926; Heimans, 1926, 1928; Van Kampen \& Heimans, 1927; Lodewijks, 1943; Zwerfmans, 1951). More is known about the last 25 years, though the information is still fragmentary (Van Bree, 1960; Van de Bund, 1964; Sijbrands, 1965; Burny, 1976; De Fonseca, 1979, 1980) or broad (Bergmans, 1981; Bergmans \& Zuiderwijk, 1986). The same applies to the eastern part of Zealand Flanders (add: Blommaart, 1953; Buise \& Sponselee, 1978).

De Fonseca (1979) had mapped the presence of Hyla arborea in the neighbouring Belgian area around Knokke and Sint-Margriete. These data complete the knowledge of the distribution range of the Tree Frog in this part of The Netherlands and Belgium.

The map (fig. 1) shows all of the distribution data collected in the present survey, from the references above, the files of the Research Institute for Nature Management, the State Forestry Service, the Herpetogeographical Service of the Lacerta Society, P. J. van der Feen, $\mathrm{Ph}$. de Fonseca, supplemented with unpublished new data from $R$. Beijersbergen, $R$. Brouwer, J. M. Burny, Mrs. L. Butler, L. d'Hoore, G. Hanekamp, E. H. Krijger, and Mrs. F. M. Zwier-de Wandel. Fig. 1 indicates that the Tree Frog is found in large parts of Zealand Flanders and that it must have been a common species in the first half of the century.

\section{Numbers}

Calling males were found in 52 pools in the study area, in which Tree Frogs were found at least once during the survey period. Countings of calling males give an impression of the densities in the separate waters (table III). Remarkable are the numerical fluctuations in a pool over the years. The recaptures have shown that

\section{TABLE II}

Sites where Hyla arborea was recorded between 1975 and 1977 for the last time. Records by J. M. Burny ( ${ }^{*}=$ pool infilled between 1977 and 1983).

\begin{tabular}{lrc}
\hline Site name & $\begin{array}{c}\text { Pool } \\
\text { no. }\end{array}$ & $\begin{array}{l}\text { Amersfoort } \\
\text { coordinate }\end{array}$ \\
\hline Oudelandse Polder & 8 & $15.360 / 376.460$ \\
Kievittepolder & 12 & $15.200 / 378.130$ \\
Cadzand & 15 & $16.765 / 377.825$ \\
Cadzand & 24 & $17.985 / 377.565$ \\
Sint Anna ter Muiden & 39 & $14.170 / 371.610$ \\
Nieuwe Passageule Polder & 108 & $23.435 / 370.140$ \\
Aardenburg & 173 & $18.375 / 366.420$ \\
Aardenburg & $223^{*}$ & $19.635 / 367.375$ \\
Bewester-Eede-benoorden- & & \\
\multicolumn{1}{c}{ Sint Pietersdijkpolder } & $222^{*}$ & $17.700 / 367.720$ \\
\hline
\end{tabular}




\section{TABle III}

Maximum numbers of Tree Frogs, observed on one evening/night during the reproduction period. Figures represent males, with females in parentheses. ( $-=$ not surveyed, $x=$ water infilled or transformed by excavation.)

\begin{tabular}{|c|c|c|c|c|c|c|}
\hline $\begin{array}{l}\text { Water } \\
\text { no. or } \\
\text { name }\end{array}$ & $\begin{array}{l}r \\
1981\end{array}$ & 1982 & 1983 & 1984 & 1985 & 1986 \\
\hline 1 & $65(4)$ & $28(3)$ & $57(24)$ & $10(1)$ & $64(12)$ & $15(3)$ \\
\hline 2 & 3 & 0 & $5(2)$ & 0 & 5 & 1 \\
\hline 3 & 0 & 0 & 0 & 0 & 0 & 3 \\
\hline 4 & 0 & 0 & 0 & 0 & 6 & 0 \\
\hline 9 & $5(2)$ & 0 & $2(2)$ & 0 & 1 & 3 \\
\hline 10 & 2 & $\mathbf{x}$ & $\mathbf{x}$ & $\mathbf{x}$ & $\mathbf{x}$ & $\mathbf{x}$ \\
\hline 11 & $26(1)$ & $8(1)$ & $9(1)$ & 0 & 3 & 7 \\
\hline 13 & $18(14)$ & $34(1)$ & $51(9)$ & 39 (2) & 15 & 35 \\
\hline 14 & 0 & 2 & 0 & 0 & 0 & 1 \\
\hline 19 & $5(1)$ & $6(1)$ & $39(1)$ & 5 & 18 & 2 \\
\hline 20 & 0 & 0 & 1 & 5 & 3 & 0 \\
\hline 25 & 0 & 0 & 0 & 0 & 3 & 3 \\
\hline 26 & 1 & 0 & 0 & 0 & 10 & 3 \\
\hline 27 & 0 & 0 & 0 & 0 & 2 & 0 \\
\hline 28 & 0 & 0 & 0 & 0 & 1 & $\mathbf{x}$ \\
\hline 30 & - & - & 1 & 0 & 20 & $\mathbf{x}$ \\
\hline 32 & 0 & 0 & 1 & - & - & 0 \\
\hline 44 & 18 & 3 & 40 & - & 1 & 10 \\
\hline 47 & $15(2)$ & $7(1)$ & 6 & - & - & 3 \\
\hline 57 & 0 & 0 & 1 & - & - & 0 \\
\hline 109 & 4 & 3 & 4 & - & - & 0 \\
\hline 110 & 0 & 0 & 1 & - & - & 0 \\
\hline 112 & 0 & 0 & 3 & - & - & 0 \\
\hline 113 & 0 & 0 & 2 & - & - & 0 \\
\hline 117 & 0 & 0 & 1 & - & - & 1 \\
\hline 174 & $28(1)$ & $10(2)$ & 10 & - & - & 1 \\
\hline 175 & $17(3)$ & 11 & $8(1)$ & - & - & 1 \\
\hline 176 ฯ & 1 & 1 & 0 & - & - & 1 \\
\hline 177 & $3(1)$ & $\mathbf{x}$ & $\mathbf{x}$ & $\mathbf{x}$ & $\mathbf{x}$ & $\mathbf{x}$ \\
\hline 179 & $8(1)$ & 3 & 0 & - & - & 0 \\
\hline 181 & 20 & 5 & 15 & - & - & 12 \\
\hline 182 & 1 & 0 & 0 & - & - & 2 \\
\hline 186 & 0 & 0 & 0 & - & - & 1 \\
\hline 195 & 0 & 2 & 0 & - & - & 0 \\
\hline 197 & 15 & 1 & $\mathbf{x}$ & $\mathbf{x}$ & $\mathbf{x}$ & $\mathbf{x}$ \\
\hline 198 & $5(1)$ & $\mathbf{x}$ & $\mathbf{x}$ & $\mathbf{x}$ & $\mathbf{x}$ & $\mathbf{x}$ \\
\hline 202 & 3 & 5 & 0 & - & - & 1 \\
\hline 203 & 8 & $7(1)$ & 7 & - & - & 1 \\
\hline 211 & 0 & $0(1)$ & 0 & 0 & 0 & 2 \\
\hline 217 & 0 & 3 & 0 & 0 & 0 & 0 \\
\hline 218 & $\mathbf{x}$ & 0 & 1 & 0 & 1 & 0 \\
\hline 221 & 5 & 0 & 0 & 0 & 0 & 0 \\
\hline 229 & 0 & 0 & $2(1)$ & - & - & 1 \\
\hline 234 & - & 2 & $17(6)$ & $5(1)$ & $19(6)$ & 3 \\
\hline 246 & 0 & 0 & 5 & 40 & 8 & 10 \\
\hline 255 & 0 & 0 & 0 & 0 & 3 & 0 \\
\hline
\end{tabular}

Tree Frogs can be sedentary or migrate over large distances. Migration was found among pools nos. 1, 13, and 19 (at distances of approx. $4 \mathrm{~km}$ from each other), where the annual numbers differ considerably and where mutual recaptures were made after one winter. Only rarely exchanges were determined between two neighbouring pools within the same season (e.g. nos. 174 and 203).

On a number of sites enough recaptures were made to allow an estimate of the total numbers per year (males only) with a derivation of the Petersen estimate (Lincoln index), by which the captures are accumulated over several days ("weighted mean", Begon, 1979).

The numbers of Tree Frogs estimated for some of the spawning waters are represented in table IV. They show that pool no. 1 (at Retranchement) and pool no. 13 (at Vlamingpolder/Cadzand-Bad) were the sites richest in Hyla arborea over the survey period. In 1985 the survey focused on Retranchement, where special attention was paid to the captures in the land habitats near pool no. 1, leading to estimate $( \pm 2 \mathrm{SD})$ the numbers for pool no. 1 and its direct surroundings (the cellar hole included) for the whole season in 1985 at $266 \pm 26$ (242 individuals caught). For males, females, and second-calendar-year juveniles, the estimates were $147 \pm 20$ (135), $95 \pm 13$ (88), and $36 \pm 36$ (19), respectively. Second-year juveniles which could be sexed later in the season were included in the male and female sections. The adjoining villages of Retranchement and Terhofstede together have 14 spawning pools. For 1985 for the whole complex an estimate of the total numbers of males, females,

\begin{tabular}{lllllll}
\hline $\begin{array}{l}\text { Water } \\
\text { no. or } \\
\text { name }\end{array}$ & 1981 & 1982 & 1983 & 1984 & 1985 & 1986 \\
\hline 256 & - & - & 0 & 0 & 3 & 1 \\
380 & 0 & 0 & 0 & - & - & 3 \\
472 & 0 & 0 & 0 & - & - & 1 \\
Veste & 0 & 0 & 6 & 0 & 10 & 2 \\
cellar & 1 & 1 & $10(7)$ & $5(2)$ & $5(9)$ & $3(3)$ \\
ditch & - & - & - & - & - & 1 \\
\hline
\end{tabular}


Table IV

Estimate $( \pm 2 \mathrm{SD}$ ) of the total number of males during the reproduction period per pool in four years, and the number of individuals caught (in parentheses). ( $-=$ not surveyed, or estimate not possible.)

\begin{tabular}{ccccc}
\hline Water no. & 1981 & 1982 & 1983 & 1985 \\
\hline 1 & $118 \pm 31(91)$ & $53 \pm 17(46)$ & $131 \pm 46(88)$ & $118 \pm 30(94)$ \\
2 & - & - & $7 \pm 4(7)$ & - \\
11 & $36 \pm 32(28)$ & $10 \pm 4(11)$ & - & - \\
13 & $18 \pm 7(18)$ & $68 \pm 18(62)$ & $117 \pm 61(64)$ & - \\
19 & - & $6 \pm 5(7)$ & $52 \pm 12(52)$ & $22 \pm 8(22)$ \\
44 & $27 \pm 15(23)$ & - & - & - \\
47 & $39 \pm 24(27)$ & - & - & - \\
174 & $38 \pm 21(34)$ & $12 \pm 9(11)$ & - & - \\
175 & $26 \pm 15(24)$ & $14 \pm 9(14)$ & - & - \\
181 & - & $4 \pm 3(5)$ & - & $27 \pm 10(27)$ \\
234 & - & - & & $24 \pm 11(24)$ \\
\hline
\end{tabular}

and second-year juveniles resulted in $397 \pm 36$ (344), based on captures in pools nos. 1, 2, 4, $25,26,30,234,256$, Veste, cellar, and the nearby land habitats.

There appears to be a relationship between the maximum number of Tree Frog males recorded on a site on one evening/night in a season and the estimate ("weighted mean") of the total number present during the reproduction period. This relationship is best fitted by the curve $y=0.749 x^{1.237}$ (fig. 3) assuming that a population is absent when it has not been recorded present (line passes through origin). The relationship can be simplified to a linear one represented by the line $y=1.73 x$, but the curve is significantly better $(P=0.0007)$. With the curve the total numbers can be predicted for the pools where an estimate was not possible owing to the lack of recaptures. This was done by fitting to a generalized linear model:

$\ln (y)=\ln (a)+(b) \ln$ (recorded number), with the assumption that the variance is directly proportional to the expectation for all observations. Based at the predictions, fig. 4 shows the fluctuations in numbers over the years for some of the pools in the Retranchement-Cadzand area and for the whole complex. With this method, the total predicted values $( \pm 2$ SD) for all pools of the study area arrive at $430 \pm 42$ (1981); $196 \pm 25$ (1982); $494 \pm 44 \quad(1983) ; 176 \pm 17$ (1984); $309 \pm 29$ (1985); $170 \pm 23$ (1986).

\section{Methodological aspects}

Hyla arborea manifested itself loudly by calling. Therefore, localization of calling males was the most productive method to spot them. But because of the large size of the study area, great effort was required to obtain a reliable picture of the actual presence of males. In several pools, mostly with bigger choruses, Tree Frogs were traced fast and easily, in others only after repeated visits, and in one not at all.

Males were calling spontaneously during the reproduction period, from mid-April until the end of June, sometimes on their daily way

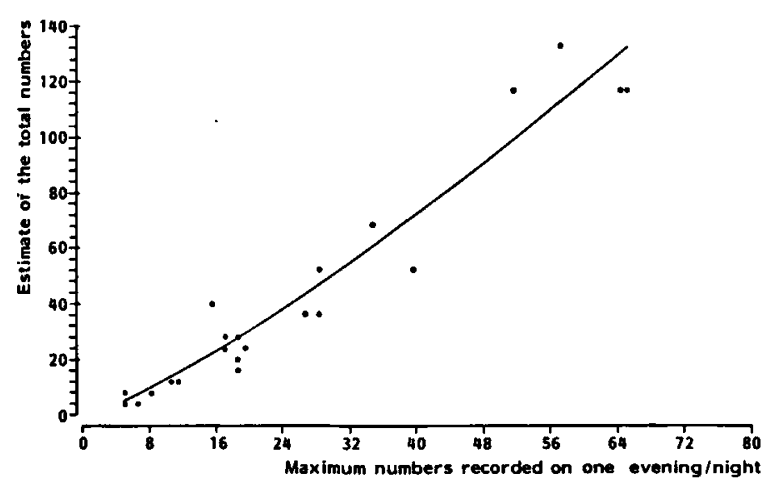

Fig. 3. Relationship between maximum number of Tree Frog males, recorded on one evening/night during a season, and the estimate ('weighted mean') of the total numbers present during the reproduction season, for a number of pools and a number of years (cf. table IV). 


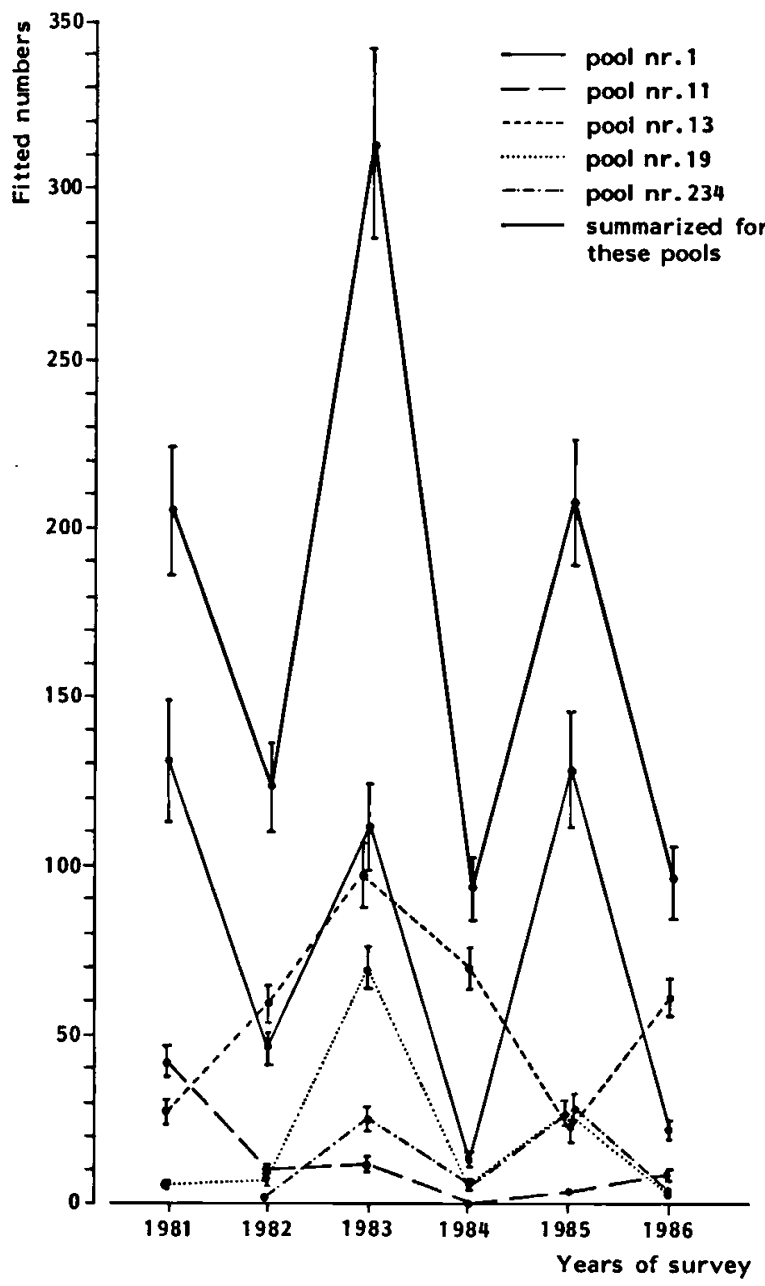

Fig. 4. Fluctuations in numbers of males (fitted) in some pools in the Retranchement-Cadzand area over six years.

towards the spawning water and especially on that very site. These mating calls were heard from shortly before evening twilight until about five o'clock in the morning (varying with weather conditions). Single mating calls could also be heard in daytime from the terrestrial vegetation. Recording a calling male at some distance was strongly affected by wind and by racket from traffic and agricultural machines. Under favourable circumstances the sound could be heard at a distance of more than $1 \mathrm{~km}$. In a pool calling activity was not heard every evening. It was not possible to predict whether any pool had chorus activity on the basis of the activity on another site. Besides, the number of calling males varied in the course of an evening/night, and often a chorus was interrupted by pauses of different lengths. During the chorus period it was also possible to evoke calling activity by playing a tape recorder with the species' mating calls at close distance (less than $25 \mathrm{~m}$ ), or by making noises such as blowing one's nose and clapping one's hands (only at the height of the chorus period). According to J. M. Burny the frogs can also respond to the jingling of a cycle bell (pers. comm.). Attempts to evoke calling activity were not always successful, e.g. when the Tree Frogs were absent or just remained silent. So, no reaction to taperecorded mating calls did not give certainty about the absence of males in pools. Nevertheless, it proved to be a good technique to trace animals faster, if present.

Counting calling males in a chorus at a distance was difficult. Choruses up to ten males could be counted fairly easily. Bigger choruses required a careful survey along the edge of the water.

Females were hard to find during the chorus period. Only very few females and amplexuses were observed in the water in the dark. In the daytime they sometimes were discovered hidden under the grass at the edge of a pool.

In the summer, from early July, no Tree Frogs were found in the water nor were mating calls heard there.

After the reproduction period adult Tree Frogs, both males and females, were found in the terrestrial vegetation in dry weather, and often fully exposed to the sun. Specimens could also be found under the same conditions in the period between hibernation and reproduction season.

During the summer period the size and colour of the vocal sac strongly decreased in some males. As the vocal sac is the main feature for sex discrimination in the field, special attention had to be given to the sexing of adults later in the season.

Outside the reproduction period, single calls were heard from the terrestrial vegetation, especially in the afternoons and the early evenings. These calls differed from the mating calls 
by being somewhat weaker, different in tone, and uttered less frequently. The calls consisted of two to six pulse groups. They were heard between hibernation and mating (earliest date: $25 \mathrm{March}$ ), and from the beginning of August until the third week of November. Evoking these calls with tape-recorded mating calls was only occasionally successful. However, this method sometimes revealed Tree Frogs, which would have passed unnoticed otherwise in the complex structure of the vegetation.

Netting for tadpoles was not very successful. The results were very poor compared with the number of eggs deposited and/or the juveniles metamorphosed; in many cases the result was even nil. Under warm weather conditions, tadpoles could be found in groups, floating directly under the water surface and above the submerged water vegetation. They are very shy then and when approached they quickly disappear into the depths.

From the metamorphosis (in hot seasons starting in the second week of July) juveniles were found at the edge of a pool or in the nearby vegetation, often clustered.

During the winter period, some fortuitous observations were made of hibernating adults in or near summer habitats. A systematic survey of hibernating animals was not possible.

\section{DISCUSSION}

This survey resulted in a number of new known sites with Hyla arborea all situated within the known range in Zealand Flanders. The atlas of the Netherlands herpetofauna (Bergmans \& Zuiderwijk, 1986), of course provided with most of the data (till 1986), gives an optimistic view of the Tree Frog situation in western Zealand Flanders because of the large quadrats $\left(25 \mathrm{~km}^{2}\right)$, with Tree Frog presence in $50 \%$ of these quadrats. In fig. 2 the quadrats are 100 times smaller and it appears that the actual distribution is scattered over only $4 \%$ of the quadrats. Recaptures have shown that the populations are not completely isolated. But as the migrants formed only a slight proportion of all recaptures, the exchange rate among populations will be low. This underlines the vulnerable position of many sites and makes the Tree Frog an ever more threatened species. Fig. 1 shows that Hyla arborea has lost a noticeable number of sites the last few decades. Burny (table II) indicates a strong numerical decrease in sites in the period 1977-1980. As the older records are not very exact, the decline cannot be expressed in a number, but it must be considerable. Worse even is the situation in eastern Zealand Flanders for which no recent records exist. Although in certain areas potential habitats still may have survived (e.g. the region of Spui-Magrette-Axel), one has to accept that Hyla arborea no longer inhabits that part of Zealand Flanders. The picture of the neighbouring Belgian West Flanders is not accurate, as it is only based on old data from De Fonseca, supplemented with incidental data for 1986.

From the low proportion of waters populated it should not be concluded that the Tree Frogs lack a proper dispersion potential, as their presence depends on a suitable combination of aquatic and terrestrial habitats, and only few land habitats were found. But also a number of waters in the study area appeared to be brackish, polluted or over-shadowed (Stumpel, in press). These were never known to have accommodated Tree Frogs.

In 1953 the sea flooded large parts of the southwestern area of The Netherlands. The consequences for the study area were such that only two areas were inundated: "Tienhonderdpolder" and "Willem-Leopold Polder". In the latter, Tree Frog activity was recorded once (pool no. 4). To what extent the flood has affected the distribution of Hyla arborea there, however, cannot be assessed, but the impact seems negligible.

Differences in presence over the years for a number of pools (table III) can be explained by dispersion and/or migration. According to Baumgartner (1986) Hyla arborea can be a wandering species. The recaptures confirm this. This had led to the situation that some pools were populated by one male Tree Frog 
only once during the survey period. They must have been migrants passing, or pioneers trying to settle somewhere. Nevertheless, they might have attracted females.

Countings of Tree Frogs differed not only considerably among pools, but also per pool per year. Differences in numbers of calling males per pool per year can be explained by fluctuations in the reproduction success in the preceding years, by migration (Stumpel \& Hanekamp, 1986), and also by varying success of the fieldwork. Nevertheless, it is presumed that all pools which were rich in Tree Frogs ( $>10$ calling males) were found. Differences in numbers among pools are also related to the size and quality of the habitats, the quality being dependent on the habitat management by man.

Some remarks have to be made on the method of estimating the numbers per pool. This weighted mean method assumes that the population is closed and that there are neither births nor deaths. These assumptions do not hold: e.g. births have been registered, deaths are most likely, and migrations have been recorded (through recaptures in other pools during the same season, but only to an insignificant fraction). Migration will interfere with the model. However, on the basis of the values found for pool no. 1 and its surroundings it is regarded realistic to assume that emigration and immigration balance each other, which keeps the model valid. Anyway, the results require a cautious interpretation. The value of the estimates lies in the mutual comparison of pools and years.

In this respect, it is one of the striking results that the numerical estimate of males in the richest pool (no. 1) is the same for 1981 and 1985 (table IV), in which years this pool was studied most intensively. It may indicate either a relationship between intensity of capturing and numbers, or the maximum density for this pool.

The recaptures also learnt that many males do not stay in the pool for the whole reproduction period. So it is impossible to count all the males in a population during a single visit. But the relationship between the maximum number of males on a site recorded on one evening/ night during a season and the estimated total number present during the reproduction period demonstrates that the number of calling males can be used as a relative measure of the size of the male population.

It should be noted that the fitted values of the estimates in pools with low numbers of males are minimum values, because most likely the real maximum number was not always determined. Therefore, fig. 4 should only show that there can be great fluctuations.

Chorus activity is influenced by air temperature, the onset of twilight (light intensity), an annual endogenous rhythm in the Tree Frog, and probably also by atmospheric pressure and the amount of precipitation (reviewed by Schneider, 1977). When a chorus calls, the sound is not of equal vocal strength during an evening and/or night: there is an optimum in chorus activity, and also pauses occur (cf. also Van Gelder \& Eijsink, 1978). As the survey visits took place at different hours of evening and night and under various weather conditions, the above will explain the differences found in chorus activity and in the responses to the tape recorder. Therefore, repeated visits at different times raise the chance of meeting calling males. But it remains remarkable that Van Bree (1960) did not discover Retranchement as a Tree Frog site, particularly because, according to the land owner, Tree Frogs have always been present there in large numbers for at least the last 50 years.

The single calling of males from the terrestrial vegetation provided an extra opportunity to find Tree Frogs in the land habitats. So, evoking these calls can be recommended for distribution surveys. Several authors mention the calls, but the difference with the mating call is not paid attention to (e.g. Lodewijks, 1943; Van Bree, 1976; Roding, 1977). Schouten (1985) described summer calls in Hyla meridionalis. His description shows resemblance 
with the sounds that have been heard in Hyla arborea. Paillette (1970) also found occasional calling during the summer in Hyla meridionalis.

As certain pools do not contain Tree Frogs every year, it is obvious that surveys have to cover more than one year in order to register all the waters suitable for Tree Frogs.

Remarkably, tadpoles were difficult to find. Probably they live in the deeper parts of a pool. Their floating behaviour may result from the need to collect thermal (solar) energy, oxygen, and/or food (algae) in the upper water layer when the weather is hot.

\section{CONSERVATION ASPECTS}

The Tree Frog populations can be classified according to the numbers of frogs and the densities of pools per site (destroyed sites not covered). This may also reflect the actual value of the sites for the survival of the whole population in Zealand Flanders:

1. The main population in the area of Retranchement/ Terhofstede.

The highest numbers of Tree Frogs were recorded in this complex. Until now, this is the biggest population in The Netherlands over the last 15 years (cf. Eijsink \& Hendriks, 1973; Van Gelder et al., 1978; Broen \& Vergoossen, 1983; Stortelder \& Reyrink, 1985; Stumpel \& Hanekamp, 1986). However, before long it may be equalled by the increasing population of central Limburg, which consisted of approx. 130 calling males in 1985 (W. Vergoossen, pers. comm.). In the summer Tree Frogs have been found in the terrestrial vegetation, spread over the whole area. The number of waters, the different positions in which they are situated in the landscape and with regard to each other, and the abundance of suitable land habitats must have caused this rich population.

2. Big populations in the Vlamingpolder (Cadzand-Bad), Kruisdijk (Sluis), and Aardenburg.

The Vlamingpolder has only two pools which contain high numbers of Tree Frogs.

Kruisdijk is a small estate (approx. 2.5 ha) with a large $\mathrm{U}$-shaped canal and surrounded by a circular dike (relevee). It is an enclave in extended arable fields. Only in 1981 permission was given to visit the canal and catch the Tree Frogs. In 1983 at some distance a minimum estimate was made of 40 calling males.

The situation in Aardenburg is similar to that in Retranchement/Terhofstede with a number of pools scattered over the edges of the town. Tree Frogs were found there in 13 different waters and on land.

3. Small populations in the Kievittepolder, Knokkert, and Driewegen.

In the Kievittepolder most Tree Frogs were found in 1981 (pool no. 11, cf. fig. 4). In 1975 Burny (1976) found the biggest population of the whole study area in the Kievittepolder. So the quality of this habitat must have decreased strongly in the last ten years. This was probably a result of the increase in shrub vegetation and the loss of some pools and a part of the summer habitat.

The Knokkert (pool no. 19) has shown a remarkable increase since 1983, which cannot be explained. The land habitat has degraded severely during the survey period by planted deciduous trees growing tall and shadowing the habitats. Restoration activities in pools nos. 20 and 218 appeared to result in colonization by Tree Frogs.

Of Driewegen countings are only available for 1981, but it is known that the Tree Frogs were still present there in four pools in 1986.

4. Low numbers in Oudelandse Polder Northwest, Nieuwe Passageule Polder West, Margueritepolder, Sint Kruis, and Groedse Duintjes.

In the Oudelandse Polder Northwest there is only one pool nicknamed the "Kikkerput" (=Frog pond) because of the clear presence of Tree Frogs in former times. It is close to the Kievittepolder and the two polders may form a complex (the distance between pools nos. 9 and 11 is $450 \mathrm{~m}$ ).

The Nieuwe Passageule Polder West contains 15 pools; Tree Frogs were found in four. The distance to the single pool in the Margueritepolder is $600 \mathrm{~m}$.

In Sint Kruis the pool area is long-drawn over $3 \mathrm{~km}$ and close to Aardenburg. Two important pools were lost (nos. 197 and 198). Now, only three pools are left, where Tree Frogs were recorded once during the survey.

The Groedse Duintjes is the only marsh area. Great parts of this site were destroyed during the survey period.

5. Occasionally, single Tree Frogs in Marolleput, Kasteelpolder, Pyramide, Cadzand-Bad, Heille.

Marolleput (no. 57), Kasteelpolder (no. 32), and Heille (no. 472) have the aspects of suitable Tree Frog pools, but the absence of land habitats is the probable reason for the absence of a population.

In Cadzand-Bad (no. 14) it is the other way round with good land habitats being available, but the pool is completely shadowed by trees.

The single observation at Pyramide possibly concerns a migrating specimen from Driewegen.

Such a classification may help to set priorities for a conservation plan. It can also be misused by declaring the lowest categories not impor- 
tant, leaving those to destruction in connection with town and country planning or changes in land use; low-density pools may play an important role as stepping-stones for connecting and expanding populations.

Publishing exact distribution data of such a threatened and vulnerable species implies some risk (collecting for pet-keeping, trade). But as the results of the survey, apart from their value for zoogeography, can be applied in nature conservation and management, the author is convinced that publication must prevail over holding the records back. No conservation and management measures can be carried out if the responsible bodies do not know where the animals live.

\section{ACKNOWLEDGEMENTS}

Many persons were involved in the intensive fieldwork. The author wishes to thank J. Coenders, the late $M$. Damoiseaux, C. Hessels, M. Hulswit, L. Huys, H. Lenders, D. Montfoort, H. Peters, and J. van Veen for their assistance, and particularly G. Hanekamp for his cooperation over a longer period. Many of the friendly people of Zealand Flanders contributed with single, but significant data. The author is indebted to J. M. Burny who placed his unpublished data at the project's disposal and made valuable suggestions at the start of the survey. Thanks are due to Dr. J. van Gelder for fruitful discussions. He also commented on the manuscript, as did Drs. W. Bergmans, Prof. Dr. R. Drent and the late Dr. D. Hillenius. Assistance with statistics was provided by Drs. J. van Biezen.

\section{REFERENCES}

Baumgartner, H., 1986. Amphibien der Schweiz. Panda, Zürich, 19 (1): 1-31.

Begon, M., 1979. Investigating animal abundance: capture-recapture for biologists: i-v, 1-97 (Edward Arnold, London).

Bergmans, W., 1981. Algemene toelichting op de verspreidingskaartjes. Verspreidingskaarten. In: $\mathbf{M}$. Sparreboom ed., De amfibieën en reptielen van Nederland, België en Luxemburg: 231-260 (A. A. Balkema, Rotterdam).

Bergmans, W. \& A. Zuiderwijk, 1986. Atlas van de Nederlandse amfibieën en reptielen en hun bedreiging. Vijfde herpetogeografisch verslag. Bibliotheek van de Koninklijke Nederlandse Natuurhistorische Vereniging, Uitgave nr. 39: i-vi, 1-177 (Uitgeverij KNNV, Hoogwoud).
Blommaart, W., 1953. Boomkikkers. De Zwerver in Gods vrije Natuur, 13: 16.

BreE, P. J. H. VAN, 1960. Aantekeningen over het voorkomen van amfibieën en reptielen in Zeeland en op Goeree-Overflakkee. Levende Nat., 63 (3): 58-67.

,-- 1976. Laat gekwaak van boomkikkers. Levende Nat., 79 (12): 279-280.

Broen, A. J. J. \&. W. Vergoossen, 1983. Zes seizoenen onderzoek en beheer van een boomkikkerpopulatie in Midden-Limburg (1978-1983). Natuurh. Maandbl., 72 (10/11): 195-202.

Buise, M. A. \& G. M. P. Sponselee, 1978. Zoogdieren, reptielen, amfibieën van O.Z.-Vlaanderen: 1-118 (mimeographed report "Vogelwacht Oost ZeeuwsVlaanderen De Steltkluut", Hulst).

Bund, C. F. VAN DE, 1964. Vierde herpetogeografisch verslag. De verspreiding van de reptielen en amphibieën in Nederland: 1-72 (Nederlandse Vereniging voor Herpetologie en Terrariumkunde "Lacerta", 's-Gravenhage).

Burny, J. M., 1976. De boomkikker: een zeldzaam bezit van Zeeuwsch-Vlaanderen. Zeeuws Nieuws over Natuur-Landschap-Milieu, 2 (3): 1-3.

Eijsink, J. G. H. M. R. H. J. J. Hendriks, 1973. Oecologie en verspreiding van Hyla a. arborea in zuid en midden Twente (1973). Mimeographed Report nr. 71, Department of Animal Ecology, Nijmegen University: 1-56.

Fonseca, PH. DE, 1979. De herpetofauna in Oost- en West-Vlaanderen. Verspreiding en functie van enkele milieufactoren: i-v, 1-278 (Ph.D. thesis, Gent University).

-, 1980 . De verspreiding van de boomkikker in Oosten West-Vlaanderen. Natuurreservaten, 27 (4bis): $38-40$.

Gelder, J. J. van, J. G. J. van den Broek, L. J. M. Stortelder \& P. B. Kelleners, 1978. De boomkikker, Hyla arborea, in Nederland. II. Migratie. Levende Nat., 81 (5): 200-205.

Gelder, J. J. van \& J. G. H. M. Eujsink, 1978. De boomkikker, Hyla arborea, in Nederland. III. Geluidsproduktie. Levende Nat., 81 (5): 218-225.

Heimans, J., 1926. Kikkers-enquête. Levende Nat., 31 (2): $52-56$.

- , 1928. Kikkers-enquête. Levende Nat., 32 (9): 291-294.

Kampen, P. N. van \& J. Heimans, 1927. Fauna van Nederland, III. Amphibia en Reptilia: 1-64 (A. W. Sijthoff, Leiden).

Lenders, H., 1986. Verslag Herpetologische Studiedagen Zeeuws-Vlaanderen, 8-11 mei 1986: 1-18 (mimeographed report "Zeeuwse Milieuferatie" \& "Herpetologische Studiegroep", Goes).

Lodewijks, J. M., 1943. De boomkikker in ZeeuwsVlaanderen. In Weer en Wind, 7 (3): 51-54.

Luiken, R., 1970. Attentie voor de boomkikker! Levende Nat., 73 (2): 36-37. 
Male, J. van, 1926. Kikkers-enquête. Levende Nat., 31 (4): 125 .

Paillette, M., 1970. La notion de territoire chez les Amphibiens Anoures, et plus particulièrement la valeur des émissions sonores dans le comportement territorial des Hylidés: Hyla arborea et Hyla meridionalis. In: G. Richard ed., Territoire et domaine vital: 35-54 (Masson et Cie, Paris).

Roding, G. M., 1977. Kwakende boomkikkers. Levende Nat., 80 (3): 71.

Roon, H. D. van, 1973. Een onderzoek naar de huidige verspreiding van de boomkikker, Hyla arborea arborea (Linnaeus), in Twente. Lacerta, 31 (7): 107-115.

Schneider, H., 1977. Acoustic behavior and physiology of vocalization in the European Tree Frog, Hyla arborea (L.). In: D. H. TAYLOR S. I. GutTMAN eds., The reproductive biology of amphibians: 295335 (Plenum Press, New York \& London).

Schouten, [J.], 1899. De boomkikvorsch. Levende Nat., 4 (3): 69 .

Schouten, J., 1985. Oecologische observaties van populaties van Hyla meridionalis, de Zuideuropese boomkikker, en Rana perezi, de Iberische meerkikker, in de Camargue, Frankrijk (vervolg). Lacerta, 43 (9/10): 158-173.

Sijbrands, S., 1965. Verslag van een onderzoek naar de verspreiding en de voortplanting van de boomkikker (Hyla arborea arborea 'Linne') in ZeeuwschVlaanderen (voorjaar en zomer 1965): 1-8 (mimeographed report, Goes).
Stortelder, A. H. F. \& L. A. F. Reyrink, 1985. Bedreiging van de boomkikker in de Achterhoek. Levende Nat., 86 (4): 130-135.

Stumpel, A. H. P., 1981a. Threats to and conservation of reptiles and amphibians in The Netherlands. In: J. Coborn ed., European Herpetological Symposium 1980: 97-100 (Cotswold Wild Life Park Ltd., Burford).

-, 1981 b. De situatie van de amfibieën en reptielen in Nederland, België en Luxemburg. In: M. SPArreвоом ed., De amfibieën en reptielen van Nederland, België en Luxemburg: 188-212 (A. A. Balkema, Rotterdam).

- , in press. Features of the aquatic habitat of Hyla arborea. In: J. J. van Gelder \& H. Strijbosch eds., Proceedings 4th Herpetological Congress of the Societas Europaea Herpetologica, Nijmegen, 17-21 August 1987.

Stumpel, A. H. P. \& G. Hanekamp, 1984. Boomkikkers. De toekomst van de boomkikker in het westen van Zeeuws-Vlaanderen. Wantij, Goes, 1 (4): 8-9, 14.

- \& -1 , 1986. Habitat and ecology of Hyla arborea in The Netherlands. In: Z. RočEK ed., Studies in herpetology. Proceedings of the European Herpetological Meeting (3rd Ordinary General Meeting of the Societas Europaea Herpetologica) Prague 1985: 409-411 (Charles University, Prague).

Zwerfmans, B., 1951. De Zeeuwse boomkikker heeft vele vrienden. Provinciale Zeeuwse Courant, 11 December 1951. 